\title{
Isolasi dan Karakterisasi Bakteri Endofit dari Tanaman Binahong dan Katepeng China
}

\author{
Desriani, Ukhradia Maharaniq Safira P, Maria Bintang, Akhmad Rivai, Puspita Lisdiyanti
}

\begin{abstract}
Abstrak
Bakteri endofit merupakan mikroorganisme menguntungkan yang berinteraksi dengan tanaman inang tanpa menyebabkan gangguan atau kerusakan pada tanaman.Beberapa studi menunjukkan bahwa bakteri endofit tertentu dapat memproduksi senyawa kimia yang memiliki efek bagi kesehatan, terutama bakteri endofit yang diisolasi dari tanaman obat.Binahong (Anredera cordifolia) dan Ketepeng Cina (Cassia alata) merupakan tanaman obat yang telah diketahui memiliki beberapa khasiat.Tujuan dari penelitian ini ialah mengisolasi dan mengkarakterisasi bakteri endofit dari kedua tanaman tersebut melalui uji antibakteriterhadap tiga jenis bakteri patogen manusia (Pseudomonas aeruginosa, Staphylococcus aureus, dan Bacillus cereus). Metode: Jumlah bakteri endofit yang berhasil diisolasi dari dua tanaman tersebut berjumlah 73 isolat (37 isolat dari Binahong dan 36 isolat dari Ketepeng Cina). Hasil: Berdasarkan uji antibakteri terhadap tiga bakteri patogen diperoleh 16 isolat bakteri endofit yang memiliki aktivitas potensial (ditandai dengan terbentuknya zona hambat), yaitu 1 isolat dari Ketepeng Cina (terhadap Pseudomonas aeruginosa) dan 15 isolat dari Binahong. Pembahasan: Terbentuknya zona hambat mengindikasikan kemungkinan adanya senyawa kimia yang memiliki efek antibakteri.
\end{abstract}

Kata kunci: bakteri endofit, Anredera cordifolia, Cassia alata, antibakteri.

\section{Abstract}

Endophytic bacteria is a beneficial microorganism that interacts with plant without causing any harm to the host. Most studies showed that certain endophytic bacteria can produce chemical compound which have medical effect, especially endophytic bacteria isolated from medicinal plant. Binahong (Anrederacordifolia) and KetepengCina (Cassia alata) are several of medicinal plants potential to be used for medical purpose. Methods: The objective of this study was to isolate and to characterize endophytic bacteria from both plants through antibacterial activity test against to three kinds of human pathogenic bacteria (Pseudomonas aeruginosa, Staphylococcus aureus, and Bacillus cereus). Results: total isolated endophytic bacteria from both plants are 73 isolates (37 isolates from Binahong and 36 isolates from KetepengCina). There were 16 isolates have potential activity (indicated by clear zone), one isolate from KetepengCina and 15 isolates from Binahong. Discussion: The formed clear zone indicates antibacterial compounds produced by endophyticbacteriatested. Further research is needed to identify the type of antibacterial compounds produced.

Keywords:endophytic bacteria, Anrederacordifolia, Cassia alata, antibacterial.

Affiliasi penulis : Research Centre for Biotechnology, LIPI. Jl. Raya Bogor Km 46, Kec. Cibinong, Kab. Bogor, 16911. Indonesia, Department of Biochemistry, Bogor Agriculture University, Indonesia Korespondensi :Desriani, Ukhradia Maharaniq Safira P, Maria Bintang, Akhmad Rivai, Puspita Lisdiyanti,. Telp: +62-21-8754587. email: gerodes@yahoo.com

\section{PENDAHULUAN}

Bakteri endofit adalah bakteri yang hidup di dalam jaringan tanaman inang tanpa menyebabkan gejala-gejala penyakit. ${ }^{1}$ Bakteri endofit masuk ke dalam jaringan tanaman umumnya melalui akar, namun bagian tanaman yang terpapar udara langsung seperti bunga, batang dan kotiledon, juga dapat menjadi jalur masuk bakteri endofit.Mikroorganisme ini dapat hidup di dalam pembuluh vaskular atau di ruang intersel, ${ }^{2}$ akar, batang, daun dan buah. ${ }^{3}$ Jumlah bakteri endofit di dalam tanaman tidak dapat ditentukan secara pasti, namun bakteri ini dapat dideteksi dengan mengisolasi pada media agar. ${ }^{4}$ Bakteri endofit dapat bersifat obligat ataupun fakultatif dalam mengkolonisasi inangnya dan pada satu tanaman inang umumnya terdiri dari beberapa genus dan spesies. ${ }^{1}$ Meskipun bakteri ini memiliki kisaran inang yang luas, namun ada beberapa bakteri endofit yang hanya dapat berasosiasi dengan inang dari famili tertentu.Simbiosis antara tanaman dengan bakteri endofit bersifat netral, mutualisme atau komensalisme. $^{4}$

Simbiosis mutualisme antara bakteri endofit dengan tanaman, dalam hal ini bakteri endofit mendapatkan nutrisi dari hasil metabolisme tanaman dan memperoteksi tanaman dalam melawan patogen, sedangkan tanaman mendapatkan derivate nutrisi dan senyawa aktif yang diperlukan selama hidupnya. ${ }^{5}$ Beberapa bakteri endofit mampu menghasilkan produk potensial antara lain : bakteri endofit Bacillus polymixa hasil isolasi dari tanaman Anuma (Artemisia annua) dapat memproduksi senyawa kimia antimalaria artemisinin di dalam media cair sintetik. ${ }^{6}$ Streptomyces griseus dari tanaman Kandelia candel menghasilkan asam $\mathrm{p}$ aminoacetophenonic sebagai antimikroba, ${ }^{7}$ Streptomyces NRRL 30562 dari tanaman Kennedia nigriscans menghasilkan munumbicin (antibiotik) dan munumbicin D (antimalaria), ${ }^{8}$ Serratia marcescens dari tanaman Rhyncholacis penicillata menghasilkan oocydin A sebagai antifungi. ${ }^{9}$ Paenibacillus polymyxadari tanaman gandum menghasilkan fusaricidin A-D sebagai antifungi. ${ }^{10}$

Binahong merupakan tanaman merambat, dengan panjang mencapai 5 meter, memiliki rizoma, batang lunak berbentuk tabung, dan umumnya berwarna kemerahan.Binahong diklasifikasikan ke 
dalam dunia Tumbuhan, superdivisi Spermatophyta, divisi Magnoliophyta, kelas Magnoliopsida, ordo Caryophynales, family Basellaceae, genus Anredera juss., spesies Anredera cordifolia (Tenore) Steenis. ${ }^{11} \mathrm{Di}$ Indonesia tanaman binahong telah digunakan untuk beberapa pengobatan seperti diabetes, kerusakan ginjal, stroke dan lain-lain.Sebuah studi menunjukkan, daun Binahong memiliki khasiat sebagai hepatoprotektor dan antioksidan pada tikus putih induksi $\mathrm{CCl}_{4}{ }^{12}$ Selain daunnya, rizoma Binahong juga memiliki kandungan alkaloid, saponin, flavonoid, dan polifenol, serta memiliki aktivitas antibakteri terhadap Staphylococcus aureus dan Escherichia coli. ${ }^{13}$ Telah dilaporkan juga bahwa daun Binahong memiliki beberapa aktivitas, yaitu antihiperlipidemia, antipiretik, analgesik, dan antiinflamasi. ${ }^{14}$

Tanaman Ketepeng Cina telah digunakan sebagai obat cacing, sariawan, sembelit, panu, kurap, kudis dan gatal-gatal.Daun Ketepeng Cina dapat mengobati konstipasi, sifilis, diabetes, intestinal parasitosis dan hernia. ${ }^{15}$ Selain itu, Ketepeng Cina banyak dimanfaatkan sebagai antiparasit, antimalaria, antiherpes, antiinfluenza dan antibronkhitis. ${ }^{16}$ Tanaman ini mengandung beberapa senyawa antara lain hidroksiantrakuinon, glikosida, asam krisofanik (chrysophanic acid), kampferin serta sannoxide A dan B. ${ }^{17}$ Ketepeng Cina (Cassia alata Lin.) diketahui memiliki efek imunomodulator terhadap aktivitas dan kapasitas fagositosis makrofag pada tikus yang diinjeksi $S$. aureus. ${ }^{16}$

Ekstrak daun dan akar Ketepeng Cina mampu menghambat pertumbuhan Streptococcus pyogenes, Staphylococcus aureus dan Proteus mirabilis secara in vitro. ${ }^{18}$ Pemberian ekstrak Ketepeng Cina terhadap tikus juga mampu menaikkan jumlah total sel darah putih secara signifikan. ${ }^{19}$ Ekstrak kasar kulit kayu Ketepeng Cina berperan sebagai antifungi terhadap Trichophyton, Microsporum dan Epidemophyton, yaitu fungi penyebab infeksi kulit ${ }^{[20]}$.Isolasi bakteri endofit dari kedua tanaman binahong dan ketepeng cina belum dilaporkan, karena itu penelitian ini bertujuan mengisolasi dan mengkarakterisasi bakteri endofit dari tanaman binahong dan ketepeng cina melalui uji antibakteriterhadap tiga jenis bakteri patogen manusia (Pseudomonas aeruginosa, Staphylococcus aureus, dan Bacillus cereus).Diharapkan isolat bakteri endofit yang diperoleh dari kedua tanaman tersebut mampu menghasilkan senyawa yang potensial sebagai antibakteri patogen.

\section{Bahan dan Metode}

Tanaman Binahong (Anredera cordifolia) dan Ketepeng Cina (Cassia alata) diperoleh dari wilayah Bogor, Jawa Barat.Isolat bakteri patogen Pseudomonas aeruginosa, Staphylococcus aureus, dan Bacillus cereus berasal dari koleksi puslit Bioteknologi LIPI Bogor.

Isolasi bakteri endofit.Bagian tanaman yang digunakan adalah akar (ujung bawah, tengah, atas), batang (ujung, tengah, bawah), daun (bawah, tengah, pucuk), rizoma akar dan rizoma batang (untuk binahong).Sampel tanamandalam keadaan segar dibersihkan dengan air mengalir kemudian dipotongpotong sepanjang $2-5 \mathrm{~cm}$ dan dipisahkan menurut bagian tanamannya. Potongan sampel tersebut kemudian disterilisasi permukaan dengan merendamnya dalam alkohol teknis selama 1 menit, larutan Chlorox $5.25 \%$ selama 5 menit, dan alkohol teknis selama 2 menit. Potongan sampel yang sudah disterilisasi dipotong-potong dan dicacah kemudian ditanam dalam media NA yang mengandung nistatin.Media yang sudah mengandung sampel tersebut diinkubasi pada suhu ruang dalam keadaan gelap dan diamati setiap hari sampai ada pertumbuhan koloni.Bakteri endofit yang tumbuh dimurnikan satu per satu dan dipreservasi dalam agar miring.

Uji aktivitas antibakteri metode cawan tuang.Satu ose bakteri patogen yang berasal dari stok agar miring diambil kemudian ditumbuhkan di dalam 5 $\mathrm{mL}$ media LB cair steril.Selanjutnya dikocok dalam inkubator dengan suhu $37^{\circ} \mathrm{C}$ selama 24 jam.Sebanyak $2.5 \mathrm{~mL}$ kultur bakteri patogen yang berasal dari media LB cair dimasukkan ke dalam $50 \mathrm{~mL}$ media LB padat yang bersuhu $35-40^{\circ} \mathrm{C}$ kemudian dituang ke dalam cawan petri sebanyak $\pm 10 \mathrm{~mL}$ lalu didinginkan. Isolat bakteri endofit yang akan diuji diletakkan ke media yang telah mengandung bakteri patogen menggunakan ose. Kultur diinkubasi selama 1-2 hari.Zona bening yang terbentuk diamati.Isolat yang mampu membentuk zona bening dikatakan potensial.

\section{HASIL DAN PEMBAHASAN}

Pada penelitian ini, telah diperoleh 73 isolat murni bakteri endofit ( 37 isolat dari Binahong dan 36 isolat dari Ketepeng Cina) (Gambar 1).Penapisan isolat bakteri endofit tersebut dilakukan untuk memperoleh isolat yang mampu menghasilkan produk metabolit yang bersifat antibakteri patogen.Pengujian secara in vitro menunjukkan bahwa produk metabolit sekunder yang dihasilkan oleh bakteri endofit menghasilkan zona hambat (Gambar 2).

Berdasarkan hasil uji aktivitas antibakteri patogen, $40.5 \%$ isolat bakteri endofit dari tanaman Binahong dan $2.77 \%$ isolat bakteri endofit dari tanaman Ketepeng Cina menunjukkan potensi antibakterinya. Empat puluh persen isolat bakteri endofit dari tanaman Binahong memiliki potensi aktivitas masing-masing terhadap $P$. aeruginosa dan $B$. cereus dan $53 \%$ terhadap $S$. aureus. Untuk Ketepeng Cina hanya 1 isolat yang memiliki potensi aktivitas yaitu terhadap $P$. aeruginosa (Tabel 1).

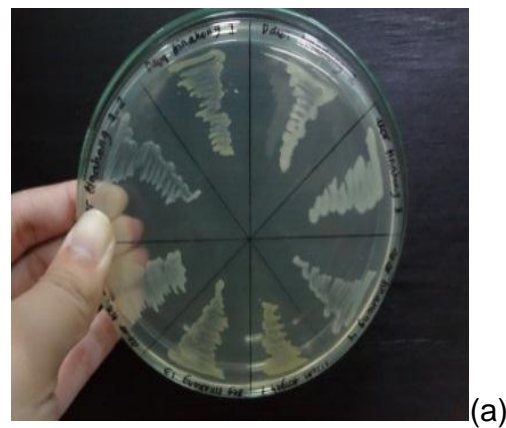



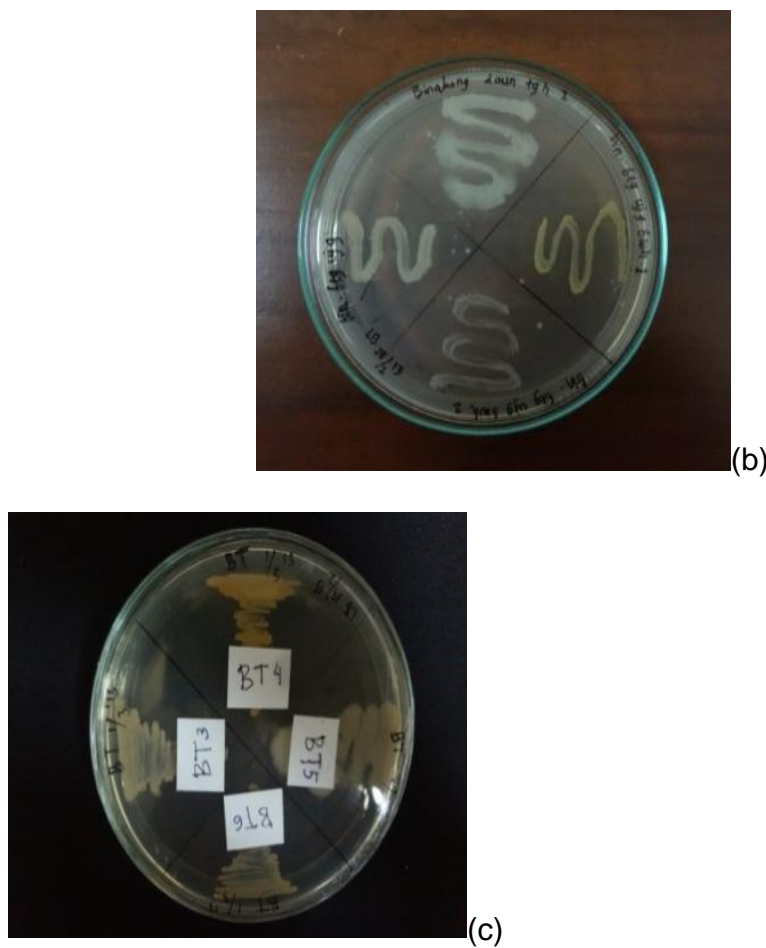

Gambar 1. Beberapa isolat murni bakteri endofit dari tanaman binahong (a dan b) dan ketepeng cina (c).
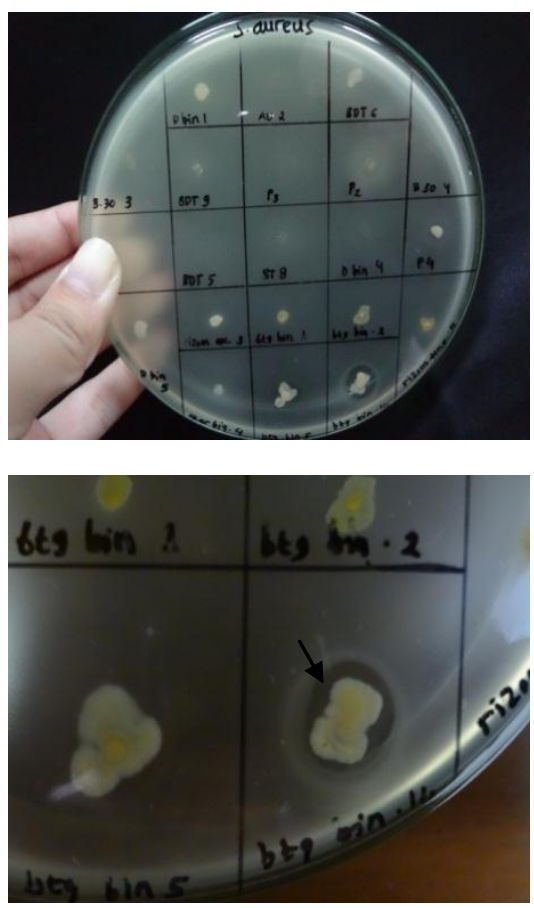

Gambar 2. Uji antibakteri isolat bakteri endofit dari binahong terhadap Staphylococcus aureus.Tanda panah menunjukkan terbentuknya zona hambat.
Tabel 1. Hasil pengujian isolat bakteri endofit terhadap bakteri patogen manusia

\begin{tabular}{llccc}
\hline $\begin{array}{l}\text { Asal } \\
\text { tanaman }\end{array}$ & Kode isolat & $\begin{array}{c}\text { P. } \\
\text { aeruginosa }\end{array}$ & $\begin{array}{c}\text { S.aur } \\
\text { eus }\end{array}$ & $\begin{array}{c}\text { B. } \\
\text { cere } \\
\text { us }\end{array}$ \\
\hline Ketepeng & P4 & + & - & - \\
Cina & & + & + & + \\
Binahong & Batang 5 & + & + & + \\
& Batang 14 & - & + & - \\
& Daun 2 & - & + & - \\
& Akar 1.2 & - & + & - \\
& Batang 15 & - & + & - \\
Batang 16 & - & + & - \\
& Akar 5.1 & - & + & - \\
& Akar 5.2 & + & - & - \\
& Daun 2.1 & + & - & - \\
& Umbi akar 1 & + & - & - \\
& Batang 3 & + & - & + \\
& Batang 4 & - & - & + \\
& Akar 4 & - & - & + \\
& Umbi tengah 6 & - & - & + \\
\hline
\end{tabular}

+ membentuk zona hambat; - tidak membentuk zona hambat

Data penelitian menunjukkan bahwa isolat bakteri endofit dari tanaman Binahong yang memiliki aktivitas potensial sebagai antibakteri sebagian besar berasal dari batang dan akar.Akar Binahong memiliki kandungan alkaloid, saponin, flavonoid, dan polifenol, serta memiliki aktivitas antibakteri terhadap Staphylococcus aureus dan Escherichia coli. ${ }^{13}$ Sedangkan pada umumnya, masyarakat menggunakan bagian daun Binahong sebagai obat. Untuk selanjutnya, hasil penelitian ini dan penelitian lain yang mendukung dapat menjadi dasar pertimbangan penggunaan akar binahong sebagai obat. Isolat bakteri endofit dengan kode Batang 5 dan Batang 14 menunjukkan aktivitas terhadap ketiga bakteri patogen.Namun, untuk bagian batang diperlukan kajian lebih lanjut mengenai kandungan senyawa dan aktivitasnya.

Berdasarkan Tabel 1 , hanya 1 isolat dari Ketepeng Cina yang menunjukkan potensi, yaitu P4 yang diisolasi dari bagian pucuk tanaman. Kemungkinan hal ini disebabkan dua hal.Pertama, bakteri endofit dari Ketepeng Cina memiliki laju pertumbuhan yang lambat sehingga hanya dapat bertahan dalam media yang mengandung bakteri patogen.Meski mampu menghasilkan senyawa antibakteri, kemungkinan jumlahnya amat sangat sedikit sehingga sulit diamati dengan mata telanjang.Kedua, kemungkinan bakteri endofit tersebut hanay dapat menghasilkan senyawa antibakteri jika berinteraksi secara in planta dengan tanaman inangnya. Sehingga, saat bakteri endofit tersebut dipisahkan dari inangnya, kemampuan menghasilkan senyawa antibakteri menjadi menurun atau justru hilang sama sekali.

Berdasarkan uji antibakteri terhadap tiga bakteri patogen diperoleh 16 isolat bakteri endofit yang memiliki aktivitas potensial (ditandai dengan 
terbentuknya zona hambat), yaitu 1 isolat dari Ketepeng Cina (terhadap Pseudomonas aeruginosa) dan 15 isolat dari Binahong. Terbentuknya zona hambat mengindikasikan kemungkinan adanya senyawa kimia yang memiliki efek antibakteri.Untuk itu diperlukan penelitian lebih lanjut tentang senyawa yang dimaksud.

\section{KESIMPULAN}

Jumlah bakteri endofit yang berhasil diisolasi dari dua tanaman tersebut berjumlah 73 isolat (37 isolat dari Binahong dan 36 isolat dari Ketepeng Cina). Berdasarkan uji antibakteri terhadap tiga bakteri patogen diperoleh 16 isolat bakteri endofit yang memiliki aktivitas potensial (ditandai dengan terbentuknya zona hambat), yaitu 1 isolat dari Ketepeng Cina (terhadap Pseudomonas aeruginosa) dan 15 isolat dari Binahong. Terbentuknya zona hambat mengindikasikan kemungkinan adanya senyawa kimia yang memiliki efek antibakteri.

\section{DAFTAR PUSTAKA}

1. Bhore SJ, Sathisha G. Screening of endophytic colonizing bacteria for cytokininlike compounds: crude cell-free broth of endophytic colonizing bacteria is unsuitable in cucumber cotyledon bioassay. World J. Agric. Sci. 2010;6(4):345-52.

2. Zinniel DK, et al. Isolation and characterization of endophytic colonizing bacteria from agronomic crops and prairie plant. Appl. Environ. Microbiol. 2002; 68(5):2198-208.

3. Simarmata R, Lekatompessy S, Sukiman H. Isolasi mikroba endofitik dari tanaman obat sambung nyawa (Gymura procumbens) dan analisis potensinya sebagai antimikroba. Berk Penel Hayati. 2007; (13):85-90.

4. Bacon CW, Hinton DM. Bacterial endophytes: the endophytic niche, its occupants, and its utility. Dalam: Gnanamanickam SS, editor. Plant-Associated Bacteria. Netherland: Springer; 2006.

5. Tanaka M, Sukiman H, Takebayashi M, Saito K, Suto M, Prana MS, Tomita F. isolation, screening and phylogenetic identification of endophytes from plants in Hokaido Japan and Java Indonesia. Microbes and Environment. 1999; 14(4):237-41.

6. Simanjuntak $P$, Bustanussalam, Otovina DM Rahayuningsih $M$, Said $E G$. Isolasi dan identifikasi artemisinin dari hasil kultivasi mikroba endofit dari tanaman Artemisia annua. [studi mikroba endofitik tanaman Artemisia spp.]. Majalah Farmasi Indonesia. 2004;15(2): 68-74.

7. Guan SH, Sattler I, Lin WH, Guo DA, Grabley S. p-Aminoacetophenonic acids produced by a mangroveendophyte: Streptomyces griseus subspecies. J Nat Prod. 2005; 68:1198-200. Dalam: Ryan RP, Germaine K, Franks A, Ryan DJ, Dowling DN. 2008. Bacterial endophytes: recent developments and applications Mini Review. FEMS Microbiol Lett. 2008; (278):1-9.

8. Castillo UF, Strobel GA, Ford EJ. Munumbicins, wide-spectrum antibiotics produced by Streptomyces NRRL30562, endophytic on Kennedia nigriscans.
Microbiology. 2002; (148):2675-85. Dalam: Ryan RP, Germaine K, Franks A, Ryan DJ, Dowling DN. Bacterial endophytes: recent developments and applications Mini Review. FEMS Microbiol Lett. 2008; (278):1-9.

9. Strobel G, Daisy B, Castillo U, Harper J. Natural products from endophytic microorganisms.J Nat Prod. 2004;(67): 25768. Dalam: Ryan RP, Germaine K, Franks A, Ryan DJ, Dowling DN. Bacterial endophytes: recent developments and applications Mini Review. FEMS Microbiol Lett. 2008;(278): 1-9.

10. Beck HC, Hansen AM, Lauritsen FR. Novel pyrazine metabolites found in polymyxin biosynthesis by Paenibacilluspolymyxa. FEMS Microbiol Lett. 2003; (220):67-73. Dalam: Ryan RP, Germaine K, Franks A, Ryan DJ, Dowling DN. Bacterial endophytes: recent developments and applications Mini Review. FEMS Microbiol Lett. 2008;(278): $1-9$.

11. Cagnotti C, McKay F, Gandolfo D. Biology and host specificity of Plectonycha correntina Lacordaire (Chrysomelidae), a candidate for the biological control of Anredera cordifolia (Tenore) Steenis (Basellaceae). African Entomology. 2007; 15(2):300-9.

12. Orbayinah S, Kartyanto A. Efikasi Binahong (Anredera cordifolia (Tenore) Steenis) terhadap kadar alkaline phosphatase. Mutiara Medika. 2008;8(2):89-95.

13. Setiaji A. Uji aktivitas antibakteri ekstrak petroleum eter, etil asetat dan etanol $70 \%$ Rhizoma Binahong (Anredera Cordifolia (Tenore) Steen) terhadap Staphylococcus Aureus Atcc 25923 dan Escherichia Coli Atcc 11229 serta skrining fitokimianya (Skripsi). Solo: Universitas Muhammadiyah Surakarta; 2009.

14. Abou-Zeid AHS, Soliman FM, Sleem A, Mitry MNR. Phytochemical and bioactivity investigations of the aerial parts of Anredera cordifolia (Ten.) Steenis. Bulletin of the National Research Centre Cairo. 2007;32(1): 31-3.

15. Abo KA, Adediwura AA, Ibikunle AJ. 1st international workshop on herbal medicinal products. University of lbadan, Ibadan, Nigeria: 1998; 22 - 24. Dalam: Makinde AA, Igoli JO, TA'Ama L, Shaibu SJ, Garba A. Antimicrobial activity of Cassia alata. Afr J. of Biotech. 2007; 6(13): 1509-10.

16. Kusmardi, Kumala S, Triana EE. Efek imunomodulator ekstrak daun ketepeng cina (Cassia alata L.) terhadap aktivitas dan kapasitas fagositosis makrofag. Makara. 2007; 11(2):50-3.

17. Makinde AA, Igoli JO, TA'Ama L, Shaibu SJ, Garba A. Antimicrobial activity of Cassia alata.Afr J. of Biotech. 2007; 6(13): 1509-10.

18. El-Mahmood AM, Doughari JH. Phytochemical screening and antibacterial evaluationof the leaf and root extracts of Cassia alata Linn Afr. J. of. Pharm. and Pharmacol. 2008; 2(7):124-9.

19. Oladunmoye MK. The immunostimulatory effects of ethanolic extract of Cassia alata on 
immune system of albino rats dosed with Staphylococcus aureus (NCIB 8588). J. of.Pharmacol. and Toxicol. 2007; 2 (2): 2004.
20. Sule WF, et al. Phytochemical properties and in-vitro antifungal activity of Senna alata Linn.crude stem bark extract. J.of.Med. Plants. Res. 2011; 5(2):176-83. 